\title{
Information Behaviour of German Youth and Their Opinions Towards Fashion Clothes
}

\author{
Beno Klemenčič \\ Faculty of Commercial and Business Sciences, Celje, Slovenia
}

\begin{abstract}
In the article we want to answer the basic research question: What kind of meaning is given to factors of information behaviour by young people from Germany aged from 20 to 24 when purchasing clothes. In the empiric part of the article, we want to achieve the following goals: (1) To find out the importance of influence of individual information sources on the purchase decision made by young people in Germany; (2) To find out how often young people in Germany buy latest fashion clothes; and (3) To compare the groups of young people from Germany with the USA on the perception of influence of individual information sources on the purchase of clothes. The data for the empiric research were collected on a sample of 230 students from several towns in Germany and in the USA. The most important information sources for young people in Germany when choosing clothes are friends and acquaintances, display windows and internet websites. Young people in Germany buy fashion clothes often repeatedly in a season. By research we found out differences in information behaviour among young people in Germany and in the USA. Likewise the discriminant analysis showed that street hoardings discriminatorily affected the common assessment of information sources. Street hoardings have a minor meaning in the USA than in Germany. Regarding their impacts we propose to companies of the fashion industry and global traders in Germany to pay more attention to hoardings on the street and to adapt to cultural characteristics of the local environment.
\end{abstract}

Keywords: consumer information behaviour, sources of information, youth, clothes

\section{Introduction}

In the process of purchase decision making information and information behaviour of consumers play an important role. From the amount of information our consumers are daily confronted with we should choose information and signals respectively important for us that would enable us to make a purchase decision. The meaning of proper, accurate and timely informing has become decisive in all fields of the public and private life. Only those who are informed have the possibility of reasonable decision making and dealing. Information behaviour of consumers usually starts with the wish of consumers for information and includes a whole of activities that serve gaining, processing, storing and further providing of the desired information. The results of the research of the consumers' information behaviour are applicable above all at the marketing science. In the empiric part, we want to find out to what extent individual information sources influence the individual's

Beno Klemenčič, M.Sc., Ph.D. candidate, Lecturer in Marketing, Faculty of Commercial and Business Sciences.

Correspondence concerning this article should be addressed to Beno Klemenčič, Ekonomska šola Murska Sobota, Noršinska ulica 13, 9000 Murska Sobota, Slovenia. E-mail: beno.klemencic@gmail.com. 
purchase of clothes. In the article we are limited to the information behaviour of young people in Germany. Germany with a population of a little more than 81 million also presents the biggest market in the EU. There are $5,022,000$ (United Nations, 2011) young people in the researched age. In the concluding part, we compared the perceived value of information sources of young people in Germany with the USA. We investigated young people aged from 20 to 24 in more detail. Knowing the market needs of consumers and understanding your customers are very important for everybody who is involved in the process of production and marketing activities (Solomon \& Rabolt, 2004, p. 25; Shulz, 2008, pp. 394-399). Information gained by researching consumers can, be used in four fields: marketing mix, segmentation, positioning and differentiation as well as environmental analysis and marketing research (Mowen, 2000, p. 17). Knowing the specific purchase and information behaviour of consumers influences the developing of the marketing mix in companies of the clothing industry. If they want to manufacture commercially successful clothes, experts have to predict consumers' tastes and understand their target market as well as adapt to it in its marketing mix elements.

\section{Information Behaviour of Young People When Choosing Clothes}

A lot of authors were trying to determine the extent of researching of consumers' information behaviour. On the basis of findings of several authors especially the following questions stand out:

- Who seeks information (persons, groups)?

- Which information (sorts of information)?

- Where?

- When and how long (phases in the purchase process)?

- Who with (participants)?

- Why (basic purpose of receiving information)?

- How (course of information activities)?

- At which products?

The basic function of clothing is to protect the body and to provide aesthetic look. Yet clothing is becoming increasingly important for the growing up youth. Clothing also enables identifying. Nowadays, young people play a central role in fashion as they are in the period of searching their own identity which is expressed and created by fashion and clothing. They can also be obsessed with their own appearances and needs (Solomon, Askegaard, Barmossy, \& Hogg, 2010, p. 439). Fashion is a broad concept which we come across in connection with different fields of the individual's life. Fashion brings benefits to young people, it guides them to their dressing style but on the other hand it can also bring different problems (economic, social, and health...). Prices of fashion clothes are usually high and they are dictated by the fashion industry. Fashion trends present an important information source for manufacturers and sellers of textile fashion products. Each manufacturer wants to manufacture and each seller wants to sell only fashion clothes which will be bought by consumers. Their wishes and needs must be everybody's guideline when making business decisions. Wishes and needs of young consumers offered to the textile industry enable a unique and conformed response to the requirements of the market. For all, who are in the clothing industry and textile companies as well as in the sales network make important business decisions in the field of designing, production and clothing sales, it is necessary to monitor fashion trends and to constantly watch and collect information on the target group of consumers. Fashion 
products also have a short life cycle (Devetak, 2007, p. 110; Solomon, 2009, pp. 622-623). Young people are an important target group for companies of the fashion industry as they set trends in fashion, music, entertainment, ideas and the ways of thinking (Kotler, 2004, p. 177). Young people have different opinions towards fashion clothes. Some believe that fashion clothes are of bad quality and made of weaker material; they are non-functional and uncomfortable and they are even bad for health because of the cut and the usage of the fabric. Successful marketeers must bear in mind that quality is of essential meaning for young consumers (Solomon, Askegaard, Barmossy, \& Hogg, 2006, p. 459). They also have different opinions towards prices of fashion clothes. Some are convinced that the clothing industry (manufacturers) does not regard the wishes of young consumers enough when developing and manufacturing clothes. By finding purchase habits of the young generation manufacturers (clothing industry) design, develop, manufacture and sell fashion clothes for young people and develop marketing strategies which arouse the consumers' interest for a determined type of product (Kotler, 2004, p. 204).

Young people bear in mind that the fashion industry sets limits to offers. Yet, they are less aware of the power and influence of different information sources above all the media and the Internet, which have an impact on their decisions. There are numerous factors that have a big influence on young people consumers. The most important is family, school, peers, fashion industry, mass media and others. Consumers often use informal or social sources (Goldsmith \& Clark, 2008) when looking for information. Consumers receive and search information about a product from different sources: sellers at shops, word-of-mouth communication from mass media (newspapers and magazines, television, catalogues and others) and lately increasingly the Internet (Peter \& Olson, 2005, p. 200; Blyte, 2008, p. 263). More and more goods are sold on the Internet. Sellers are convinced that goods are sold better and faster on the Internet (Rickman \& Cosenza, 2007). The basic commercial information sources at the purchase of clothes are: radio commercials, TV shows and commercials, magazines about fashion and clothes, catalogue sales, the Internet and others. Marketers will have to pay more attention to the Internet. Virtual societies such as MySpace.com, Facebook and Twitter offer forums where consumers can connect with their friends and share diverse information. Consumers can join interest groups which are connected with fashion and express their favors for a definite brand as well as share their opinions with the broader public (Thomas, Peters, \& Tolson, 2007, pp. 587-603).

\section{Research Methodology}

In the article, we want to answer the basic research question: What kind of meaning is given to factors of information behaviour by young people from Germany aged 20 to 24 when purchasing clothes.

In the empiric part of the article we want to achieve the following goals: (1) To find out the importance of influence of individual information sources on the purchase decision making of young people in Germany; (2) To find out how often young people in Germany buy latest fashion clothes; and (3) To compare the groups of young people from Germany with the USA on the perception of influence of individual information sources on the purchase of clothes. The importance of influence on individual information sources in Germany and the USA is ascertained with the following hypotheses:

HA1: The groups of young people from Germany and the USA significantly differ in the perception of the influence of individual information sources on the purchase of clothes. 
HA2: No individual information source discriminatorily influences the assessment of the common influence of information with young people in Germany and the USA.

\section{Research Sample}

The sample of the quantitative research, $n=230$, presents students aged from 20 to 24 from Germany and the USA. There were 120 students from Germany and 110 students from the USA included in the quota sample.

\section{Research Procedure}

The inquiry was carried out between the 15 June 2011 and the 15 October at faculties in Germany (Berlin, Essen, Marburg in Ingolstadt) and in the USA (Boston (Massachusetts), Austin (Texas), Fort Wayne (Indiana) and Berkeley (California)).

The questionnaire contains 30 questions. The students were provided with the questionnaire in German and in English. The central part of the questionnaire includes two fields: (1) Perception of the influence of individual information sources on the purchase of clothes; and (2) Opinions towards fashion clothes.

In the central parts the questionnaire contains the many-level Likert scale from 1 to 5 by which the interviewees assessed the perception of the influence of information sources on the purchase decision (where grade 1 means totally nothing, grade 5 means totally) and the opinion towards fashion clothes (where grade 1 means I do not agree at all, grade 5 means I absolutely agree with the statement). The many-level scale was also used in previous research of consumer behaviour and their opinions.

\section{Data Analysis and Discussion}

The input and analytical processing of data were carried out by the statistics software IBM SPSS Statistics 19. Data processing shows descriptive statistics, $t$-test and discriminant analysis. In the continuation of the article the explanation of the most important findings of the carried out research follows.

Two hundred and thirty young people from Germany and the USA aged from 20 to 24 were included in the research. The profile of interviewees by country and gender is shown in Table 1.

Table 1

Profile of Interviewees by Country and Gender

\begin{tabular}{llccc}
\hline & & \multicolumn{2}{c}{ Gender } & Total \\
\cline { 3 - 5 } & & Male & Female & 120 \\
Country & Germany & 61 & 59 & 110 \\
Total & USA & 57 & 53 & 230 \\
\hline
\end{tabular}

With the research we wanted to find out about the perception of the influence of individual information sources on the purchase of clothes. In the survey interviewees assessed the influence of individual information sources on the purchase of clothes. The results are shown in Table 2.

In Table 2, it is evident that the biggest influence on the purchase decision of the German youth aged from 20 to 24 when choosing clothes has the following information sources: friends and acquaintances (3.35), display windows (3.14), and Internet websites (2.81). Catalogue sales, advertisements and articles in newspapers, fashion magazines and hoardings on the streets. Radio commercials, social networks and direct mail have the smallest influence. We also researched the opinions of German youth towards fashion clothes. The results are shown in Table 3. 
Table 2

Influence of Information Source on the Purchase Decision

\begin{tabular}{llllll}
\hline & No. & Minimum & Maximum & Mean & Std. deviation \\
\hline Radio advertisement & 120 & 1 & 5 & 1.27 & 0.916 \\
Ads and shows on TV & 120 & 1 & 5 & 2.09 & 1.123 \\
Ads and articles in newspapers & 120 & 1 & 5 & 2.36 & 1.194 \\
Fashion magazines & 120 & 1 & 5 & 2.35 & 1.320 \\
Catalogue selling & 120 & 1 & 5 & 2.49 & 1.309 \\
Display windows & 120 & 1 & 5 & 3.14 & 1.147 \\
Direct mail & 120 & 1 & 5 & 1.98 & 1.137 \\
Friends and acquaintances & 120 & 1 & 5 & 3.35 & 1.186 \\
Clothes seller & 120 & 1 & 5 & 2.25 & 1.139 \\
Hoardings on the streets & 120 & 1 & 5 & 2.28 & 1.161 \\
Websites on the Internet & 120 & 1 & 5 & 2.81 & 1.285 \\
Facebook, MySpace, Twitter & 120 & 1 & 5 & 1.65 & 1.135 \\
Valid $N$ (listwise) & 120 & & & & \\
\hline
\end{tabular}

Table 3

\section{Opinions of German Youth Towards Fashion Clothes}

\begin{tabular}{|c|c|c|c|c|c|}
\hline & No. & Minimum & Maximum & Mean & Std. deviation \\
\hline Fashion clothes producers pay regard to wishes of young people. & 120 & 1 & 5 & 3.33 & 0.956 \\
\hline Fashion clothes are of bad quality (poorer material, harder maintenance...). & 120 & 1 & 5 & 2.28 & 1.037 \\
\hline Fashion clothes are not functional and uncomfortable. & 120 & 1 & 5 & 2.38 & 0.979 \\
\hline $\begin{array}{l}\text { Fashion clothes are harmful to health (wide neck, short vests, light materials in } \\
\text { winter, ...). }\end{array}$ & 120 & 1 & 5 & 2.08 & 1.050 \\
\hline Fashion for young people changes too fast. & 120 & 1 & 5 & 2.91 & 1.167 \\
\hline Market prices for fashion clothes are too high. & 120 & 1 & 5 & 3.47 & 1.195 \\
\hline I can use fashion clothes for many seasons. & 120 & 1 & 5 & 4.10 & 0.999 \\
\hline Fashion clothes improve my self-image. & 120 & 1 & 5 & 3.35 & 1.281 \\
\hline Fashion clothes attract attention with people. & 120 & 1 & 5 & 3.36 & 1.098 \\
\hline Valid $N$ (listwise). & 120 & & & & \\
\hline
\end{tabular}

From Table 3, it is evident that the interviewees have the opinion that fashion clothes can be used in more seasons (4.10). On the basis of high average grades we found the following: Market prices of fashion clothes are too high, manufacturers pay attention to the wishes of young people, fashion clothes increase the self-image of young people and fashion clothes attract attention with people. We found that young people disagree with the belief that fashion clothes are harmful to health.

Table 4 shows the frequency of purchasing latest fashion clothes. We found that the biggest share of the interviewees buying latest fashion clothes often (repeatedly in a season). Some few buy them rarely (once a season).

Table 4

Frequency of Purchases of Latest Fashion Clothes

\begin{tabular}{llcccc}
\hline & Frequency & Percent & Valid percent & Cumulative percent \\
\hline Valid & Never & 10 & 8.3 & 8.3 & 8.3 \\
& Rarely (once a season) & 45 & 37.5 & 37.5 & 45.8 \\
& Often (repeatedly in a season) & 58 & 48.3 & 48.3 & 94.2 \\
Very often (repeatedly in a month) & 7 & 5.8 & 5.8 & 100.0 \\
& 120 & 100.0 & 100.0 & \\
\hline
\end{tabular}


The set alternative hypothesis $\mathrm{H} 1$ is tested with the $t$-test (independent samples $t$-test procedure). The hypothesis is accepted if the characteristics level is $P(\alpha=0.05)$, which means that the difference is characteristic. In case that the stated conditions are met only with individual factors, the alternative hypothesis is partly accepted with the declaration of the factor. The results of the $t$-test are shown in Table 5. The results of the $t$-test show that the alternative hypothesis H1 is partly accepted. Differences between young people in Germany and the USA are typical for the following information sources: advertisements and articles in newspapers, display windows, direct mail and hoardings on the streets. For the stated sources, we accept the alternative hypothesis on the basis of the sampled data.

Table 5

T-test of Differences Between Arithmetic Means of Grade of Two

\begin{tabular}{lrll}
\hline & \multicolumn{1}{c}{$t$} & $d f$ & Sig. (2-tailed) \\
\hline Radio advertisement & 0.021 & 228 & 0.983 \\
Ads and shows on TV & -10.561 & 228 & 0.120 \\
Ads and articles in newspapers & 30.149 & 228 & 0.002 \\
Fashion magazines & 0.778 & 228 & 0.438 \\
Catalogue selling & 0.978 & 228 & 0.329 \\
Display windows & 40.032 & 228 & 0.000 \\
Direct mail & 20.257 & 228 & 0.025 \\
Friends and acquaintances & 0.133 & 228 & 0.894 \\
Clothes seller & -0.986 & 228 & 0.325 \\
Hoardings on the streets & 50.738 & 228 & 0.000 \\
Websites on the Internet & 10.643 & 228 & 0.103 \\
Facebook, MySpace, Twitter & -0.398 & 228 & 0.691 \\
\hline
\end{tabular}

For the information sources: radio commercials, TV ads and shows, fashion magazines, catalogue sales, friends and acquaintances, clothes sellers, Internet websites, and social networks the $t$-test results show no typical differences. On the basis of the sampled results, we accept the null hypothesis that young people from both countries do not differ in the assessment of the stated sources.

The set alternative hypothesis 2 that no individual information source affects the assessment of the common influence of information discriminatorily with young people in Germany and the USA was checked by discriminant analysis with two groups.

Table 6

Eigenvalues and Wilks' Lambda Table

\begin{tabular}{lllll}
\hline Function & Eigenvalue & \% of variance & Cumulative $\%$ & Canonical correlation \\
\hline 1 & $0.364^{\text {a }}$ & 100.0 & 100.0 & 0.516 \\
\hline Wilks' Lambda & & & & \\
\hline Test of function(s) & Wilks' Lambda & Chi-square & df & Sig. \\
\hline 1 & 0.733 & 68.873 & 12 & 0.000 \\
\hline Note ${ }^{\text {a }}$ First 1 canonical discriminant functions were used in the analysis. &
\end{tabular}

Eigenvalue is 0.364 , which indicates a worse discriminant function. The coefficient of the canonical correlation is 0.516 and it shows that there is a connection between the discriminant function and the groups. Wilks' lambda is 0.733 , which means that the arithmetical mean of discriminant values between the groups is not 
typically different. As the level of characteristic in our case is less than 0.05 , we can accept the alternative assumption of differences of arithmetical means of the groups' discriminant values with the risk less than 0.05 .

From Tables 7 and 8, it is evident that the groups of young people in Germany and the USA differ by the influence of sources. Hoardings on the street discriminatorily affect the assessment of the common information influence with young people in Germany and the USA.

Table 7

Standardised Canonical Discriminant Function Coefficients Table

\begin{tabular}{lc}
\hline & Function \\
\cline { 2 - 2 } & 1 \\
\hline Radio advertisement & -0.049 \\
Ads and shows on TV & -0.648 \\
Ads and articles in newspapers & 0.341 \\
Fashion magazines & -0.066 \\
Catalogue selling & 0.053 \\
Display windows & 0.473 \\
Direct mail & 0.058 \\
Friends and acquaintances & 0.020 \\
Clothes seller & -0.426 \\
Hoardings on the streets & 0.740 \\
Websites on the internet & 0.153 \\
Facebook, MySpace, Twitter & -0.162 \\
\hline
\end{tabular}

Table 8

Structure Matrix Table

\begin{tabular}{lc}
\hline & Function \\
\cline { 2 - 2 } & 1 \\
\hline Hoardings on the streets & 0.630 \\
Display windows & 0.443 \\
Ads and articles in newspapers & 0.346 \\
Direct mail & 0.248 \\
Websites on the Internet & 0.180 \\
Ads and shows on TV & -0.171 \\
Clothes seller & -0.108 \\
Catalogue selling & 0.107 \\
Fashion magazines & 0.085 \\
Facebook, MySpace, Twitter & -0.044 \\
Friends and acquaintances & 0.015 \\
Radio advertisement & 0.002 \\
\hline
\end{tabular}

Note. Pooled within-groups correlations between discriminating variables and standardized canonical discriminant functions; Variables ordered by absolute size of correlation within function.

Table 9

Classification Results Table

\begin{tabular}{|c|c|c|c|c|c|}
\hline & & \multirow{2}{*}{ Country } & \multicolumn{2}{|c|}{ Predicted group membership } & \multirow{2}{*}{-Total } \\
\hline & & & Germany & ZDA & \\
\hline \multirow[t]{4}{*}{ Original } & Count & Germany & 83 & 37 & 120 \\
\hline & & USA & 28 & 82 & 110 \\
\hline & $\%$ & Germany & 69.2 & 30.8 & 100.0 \\
\hline & & USA & 25.5 & 74.5 & 100.0 \\
\hline
\end{tabular}

Note. $71.7 \%$ of original grouped cases correctly classified. 
The classification matrix shows the number is correctly classified units in the group by discriminant function. The program correctly classified $71.7 \%$ of the treated units.

On the basis of the findings of the discriminant analysis, we reject the set alternative hypothesis 2 . By discriminant analysis we namely find out that hoardings on the street are that source of information which contributes to the difference in assessing the sources as a whole.

\section{Conclusion}

In the article, we treat the information behaviour of the German youth aged from 20 to 24 when choosing clothes and their opinions towards fashion clothes. There are more than five million young people in Germany in the stated age and they present an important market segment. Consumers gain their information from different sources. The most important information sources for young people in Germany when choosing clothes are friends and acquaintances, display windows and Internet websites, then catalogue sales, advertisements and articles in newspapers, fashion magazines, hoardings on the streets and others. The findings of numerous researches show that the share of young people using social networks (Facebook and others) is increasing but in this research, we find that they do not have a bigger influence on purchase decisions regarding the choice of clothes. Young people are an important target group for companies of the fashion industry as they set trends in fashions. Young people have different opinions towards fashion clothes. For the German youth, we find that they have the following opinions towards fashion clothes: fashion clothes can be used more seasons, market prices for fashion clothes are too high, manufacturers of fashion clothes pay attention to wishes of young people, fashion clothes attract attention with people and other. Young people buy fashion clothes often (repeatedly in a season). By research, we also try to find differences in information behaviour among young people in Germany and the USA. We found out that there are typical differences among young people in the researched/studied countries regarding the influence of individual sources on purchase decisions. Likewise the discriminant analysis showed that street hoardings discriminatorily affect the common assessment of information sources. Street hoardings have a minor meaning in the USA than in Germany. Regarding their impacts we propose companies of the fashion industry and global traders in Germany to pay more attention to hoardings on the street and to adapt to cultural characteristics of the local environment.

Cognitions of the information behaviour of consumers and knowing the opinions of consumers towards fashion products offer a lot of supporting points for forming practical measures in the clothing and fashion industry from the marketing point of view.

\section{References}

Angus, I., \& Jhally, S. (1989). Cultural Politics in Contenporary America. New York, London: Routledge.

Blythe, J. (2008). Consumer behavior. London: Thomson Learning.

Devetak, G. (2007). Marketing management. Koper: Fakulteta za management.

Ersun Nur, A., \& Yildirim, F. (2010). Consumer involvement and brand sensitivity of university students in their choice of fashion products. Retrieved from http://www.iibf.marmara.edu.tr/dosya/fakulte/iibfdergi_2010_1/17_ersun-yildirim.pdf

Goldsmith, R. E., \& Clark, R. A. (2008). An analysis of factors affecting fashion opinion leadership and fashion opinion seeking. Journal of Fashion Marketing and Management, 12(3), 308-322.

Kotler, P. (2004). Management trženja. Ljubljana: GV založba.

Mowen, J. C. (2000). Consumer behavior. New Jersey: Prentice Hall. 
Peter, J. P., \& Olson, J. C. (2005). Consumer behavior and marketing strategy. Boston: Irwin McGraw-Hill.

Rickman, T. A., \& Cosenza, R. M. (2007). The changing digital dynamics of multichannel marketing: The feasibility of the weblog: Text mining approach for fast fashion trending. Journal of Fashion Marketing and Management, 11(4), 604-621.

Shulz, S. (2008). Our Lady Hates Viscose: The role of the customer image in high street fashion production. Cultural Sociology, 2(3), 385-405.

Solomon, M. R. (2009). Consumer behavior: Buying, having and being. Pearson Education. New Jersey: Upper Saddle River.

Solomon, M. R. (2011). Consumer behavior: Buying, having and being. New Jersey: Pearson Education.

Solomon, M. R., \& Rabolt, N. J. (2004). Consumer Behavior: In fashion. Second Edition. New Jersey: Prentice Hall.

Solomon, M. R., Askegaard, S., Barmossy, G., \& Hogg, M. (2006). Consumer behavior: A European perspective. Harlow: Financial Times/Prentice Hall.

Solomon, M. R., Askegaard, S., Barmossy, G., \& Hogg, M. (2010). Consumer behavior: A European perspective. Harlow: Financial Times/Prentice Hall.

Taylor, S. L., \& Cosenza, R. M. (2002). Profiling later aged female teens: male shopping behaviour and clothing choice. Journal of Consumer Marketing, 19(5), 393-408.

Thomas, B. J., Peters, C. O., \& Tolson, H. (2007). An exploratory investigation of the virtual Community MySpace.com: What are consumers saying about fashion? Journal of Fashion Marketing and Management, 11(4), 587-603.

United Nations. (2011). World population prospects, the 2010 revision. Retrieved from http://esa.un.org/wpp/Excel-Data/population.htm 